anales de psicología / annals of psychology

2020, vol. 36, $\mathrm{n}^{\circ} 1$ (january), 1-11

https://doi.org/10.6018/analesps.343501
(C) Copyright 2020: Editum. Servicio de Publicaciones de la Universidad de Murcia. Murcia (Spain) ISSN print edition: 0212-9728. ISSN on line edition (http://revistas.um.es/analesps): 1695-2294.

On line edition License Creative Commons 4.0: BY-NC-ND

\title{
Strength-based approach for building resilience in school children: The case of Gaza
}

\author{
Suhayla Jalala, Gözde Latifoğlu, and Hüseyin Uzunboylu \\ Near East University / Yakin Doğu Üniversitesi (Nicosia, North Cyprus, Turkey)
}

\begin{abstract}
Título: Enfoque basado en la fortaleza para desarrollar la resiliencia en los escolares: El caso de Gaza.

Resumen: Este artículo busca desarrollar un "enfoque proactivo basado en la fortaleza para fomentar la resiliencia de los niños en edad escolar" en situaciones de crisis política, para ser utilizado por los orientadores en las escuelas de Gaza, con el fin de promover programas de aprendizaje social y emocional que mejoren la resiliencia y el bienestar de los estudiantes. Se utilizó un enfoque metodológico mixto para recopilar y analizar los datos. Los métodos cualitativos incluyeron la recopilación de datos mediante la revisión de la literatura, 12 entrevistas con directores de escuelas y psicólogos y 12 grupos focales con padres, orientadores y maestros. El método cuantitativo incluyó la recolección de datos utilizando un cuestionario autoadministrado por los estudiantes de la muestra. La población de estudio estaba compuesta por todos los estudiantes de los grados de educación básica en la ciudad de Gaza. La muestra de estudio fue aleatoria y consistió en 619 estudiantes. El análisis estadístico se utilizó para analizar el cuestionario y el análisis de contenido para analizar los datos cualitativos. Los hallazgos obtenidos en este estudio reflejaron que tanto los métodos cualitativos como los cuantitativos resaltaron factores de fortaleza similares que apoyan la creación de resiliencia entre los escolares de Gaza. Definen la capacidad de los niños para adaptarse y tener éxito a pesar de las difíciles condiciones que los rodean, el pensamiento positivo de los niños, la provisión de cuidados, la creación de un entorno escolar de apoyo, la incorporación de temas de resiliencia en el currículo, la participación de los niños en talleres de resiliencia, la construcción de relaciones sólidas entre la escuela y la familia, grupos y buenas relaciones con vecinos y familiares. En conclusión, este estudio se presenta como el primer esfuerzo para desarrollar un modelo conceptual de enfoque proactivo basado en la fortaleza para orientadores en la ciudad de Gaza y otras ciudades que experimentan una inestabilidad política similar para aplicar enfoques efectivos para fomentar el aprendizaje académico, la resiliencia y el bienestar de los niños en edad escolar.

Palabras clave: Resiliencia; Enfoque basado en la fortaleza; Niños en edad escolar; Ciudad de Gaza; Crisis política.
\end{abstract}

\section{Introduction}

There are risk factors facing children at individual, family, school and community levels (Rowe \& Stewart, 2009). These risk factors could have an impact on the social, mental and physical health of individuals (Babayigit \& Okray, 2018; McCann et al., 2013; McDonald, Jackson, Wilkes \& Vickers, 2013; Pinar, Yildirim \& Sayin, 2018; Szeri, Şahin, Cevahir \& Say, 2010). Therefore, resilience is considered as one of the important interventions that protects children from the negative impacts of risk factors and offers operational source of coping (McGillivray \& Pidgeon, 2015; Pinar, Yildirim \& Sayin, 2018; Zhao Guo, Suhonen \& Leino-Kilpi, 2016). So, understanding factors that help promote resilience can be in-

* Correspondence address [Dirección para correspondencia]:

Suhayla Jalala. Near East University / Yakın Doğu Üniversitesi (Nicosia,

Turkey). E-mail: soh990@hotmail.com

(Article received: 25-9-2018; revised: 21-3-2019; accepted: 27-7-2019)
Abstract: This paper seeks to develop a "Strength-based proactive approach for building resilience in school children" under political crisis to be used by counsellors within Gaza schools to advance social and emotional learning programmes that enhance students' resilience and wellbeing. A mixed-methodological approach was used to collect and analyse the data. The qualitative methods included the data collection using literature review, (12) interviews with school principals and psychologists and (12) focus groups with parents, counsellors and teachers. The quantitative method included data collection using (619) students' self-administered questionnaires. The study population consisted of all the students of basic education grades in Gaza city. The study sample was random and consisted of (619) students. Statistical analysis was used to analyse the questionnaire and the content analysis was used to analyse qualitative data. Findings obtained in this study reflected that both qualitative and quantitative methods highlighted similar strength factors that support building resilience among school children in Gaza. They define children's ability to adapt and succeed despite the difficult conditions surrounding them, child positive thinking, providing care, creating a supportive school environment, incorporating resilience topics in curriculum, engaging children in resiliency workshops, building strong relationships between school and family, joining peer groups and building good relationship with neighbours and relatives. In conclusion, this study comes as the first effort to develop Conceptual Strength-Based Proactive Approach model for counsellors in Gaza city and other cities experiencing similar political instability to apply effective approaches for fostering academic learning, resilience and wellbeing of school children.

Keywords: Resilience; Strength-Based Approach; School children; Gaza city; Political crisis. formative for designing preventative interventions (Beardslee, Solantaus, Morgan, Gladstone, \& Kowalenko, 2012; Mahedy et al., 2018).

Resilience is described as the successful adaptation and functioning within threatening adverse events (Luthar, Cicchetti \& Becker, 2000). Accordingly, resilience has two main aspects, including the surrounding circumstances that disturb the development of children as well as children's successful dynamic adaptation (Rutter, 1979; Rutter, 2006). However, resilience is not only the ability to overcome the threats but also external strength factors, including educational and family support (Chu, Sen, Saucier, \& Hafner, 2010; Go, Chu, Barlas \& Chng, 2017). Resilience strengthens adaptation, Resilience strengthens adaptation, promotes recovery, protects mental health, and maintains integrated positive functioning over the passage of time in the aftermath of adversity (Lou, Taylor \& Di Folco, 2018; Southwick, Bonanno, Masten, Panter-Brick \& Yehuda, 2014). 
Conceptualizing resilience in children marks salient internal factors including biological and psychological factors, while external factors are reflected in the nature and quality of relationships established within or outside the family group (Jenney, Allagia \& Niepage, 2016). Likewise, Rojas (2015) (as cited in Johnson, 1997) suggests that human relationships are the most critical factor in school child resiliency, followed by child attributes, school programs, community variables, and family factors. Internal factors are the personal attributes of the resilient children, such as empathy and selfesteem (Dumont \& Provost, 1999; Karatas, Tagay \& Cakar, 2016; Masten \& Gramezy, 1985; Rutter, 1987) self-efficacy (Masten \& Coatsworth, 1998; Al-Bataineh, Brenwall, Stalter \& York, 2019) and intellectual functioning (Freitas \& Downey, 1998; Masten et. al., 1999). Contextually related external factors include positive peer influence, supportive family peers, caring school and community environments (Luthar, Cicchetti \& Becker, 2000; Masten, Best \& Garmezy, 1990; Werner \& Smith, 1982).

The school plays a significant role in contributing to children's wellbeing, resilience and academic learning by following a strengths-based perspective model (Seligman, Ernst, Gillham, Reivich \& Linkins, 2009). The strengths-based perspective can provide advantages to teachers that extends the resilience paradigm currently accepted within school education (Brownlee, Rawana \& MacArthur, 2012). The school resiliency factors consist of two broader categories, including school culture (McCashen, 2005; O'Connell, 2006) and commitment to learning at school (Cetinkaya, 2019; Walsh \& Park-Taylor, 2005). Children's personality positive development is mostly determined by the commitment of effort and time they give in their schools and the impact of school teachers, school peer groups, and school- parent schoolcommunication to become highly educated and socially effective responsible individuals (Plotnikova, \& Strukov, 2019; Mukhopadhyay, 2010).

Benson (1997) views resilience as a paradigm shift from identifying individual's risk factors to identifying individual's strengths. A resilient individual is characterized by stressresistance and less vulnerable despite experiencing significant adversity (Garmezy, \& Masten, 1994; Garmezy, 1996). Accordingly, interventions have moved increasingly toward creating a coordinated sequence of positive experiences and providing key developmental supports and opportunities (Alvord \& Grados, 2005). Rather than the traditional perspective of engaging an individual with a problem orientation and risk focus, a strength-based approach seeks to understand and develop the strengths and capabilities that can transform the lives of people in positive ways (Barton, 2005).

A strengths-based approach is linked to the traditional foundation of counselling and guidance since this approach emphasises human development, prevention, positive assets, wellness, and strengths, rather than weaknesses and psychopathology (Ratanavivan, 2015; Lotfi, 2007). It operates from the assumption that resources and strengths available within and to children that help them improve participation and achieve success in many areas of their life (Hollenbeck \& Morris, 2016; Trujillo, 2017). It pursues to understand and advance the capacities and strengths that can transform the lives of children in positive ways (Alvord \& Grados, 2005; Barton, 2005). Accordingly, much of the interventions on promoting children development have been shifted from focusing on vulnerabilities and mitigating risks to an emphasis on nurturing strengths, capabilities and resources of a child (Ager, 2013; Almedom \& Glandon, 2007; Namy et al., 2017).

Worldwide, interest in strength-based approach has increased considerably as a means to improve the positive development of school children as counsellors, researchers, educators, practitioners and community care providers shift from the prevention of specific problems to a more holistic concentration on positive factors of children development (Alberta, 2012). Counsellors using a strengths-based approach perceive that each child has strengths to cope with difficulties and to maintain functioning in the stress (Brasler, 2001). Thus, counsellors develop treatment plans based on children's attainment of skills, competence, interests, motivation, emotions and resources (Bozic, 2013). This will help children move forward from problem-talking in the past to realistic expectation and solutions in the future (Colville, 2013; Hughes, 2014). Apart from the individualised perspective, some professionals of student affairs use a strengthsbased approach to link their education programmes with larger institutional objectives, including student engagement, retention, and success (Soria \& Stubblefield, 2015). However, academic achievement of students declines during the preparatory school and children's low achievement is the biggest challenge facing today's schools (Dukmak \& Ishtaiwa, 2015).

Four overlapping waves of resilience research have been conducted over four decades (Marie \& Johns, 2018) including: 1 . individual traits, 2 . protective mechanisms, 3. developmental assets at individual and community levels and 4 . social ecological: culturally entrenched understanding of resilience and 'new voices' (Sagone \& Elvira De Caroli, 2016; Ungar, 2012; Ungar, Brown, Liebenberg \& Othman 2007; Masten, 2007). The first wave of research was emerged around 1970 on resilience in the behavioural sciences where the initial conceptualisation of resilience focused on individual traits (Anthony, 1987; Garcia-Dia, DiNapoli, Garcia-Ona Jakubowski \& O'flaherty, 2013). The second wave attempted to conceptualise resilience as a dynamic process and the interaction between genetic and environmental factors (Rutter, 2012) so that the resilience can be a process of using internal and external protective factors to adapt to a situation (Garcia-Dia et al., 2013). The third wave of resilience conceptualisation is the shift to developmental assets, both individual and community where scholars argued that resilience can be an outcome of interactions between individuals and their environments (Ungar, 2008), children's resilience in schools can be enhanced by focusing on individual and environmental factors (Bosworth \& Earthman, 2002; Masten, 2001). The fourth wave of resilience science viewed the cultural context 
to play a significant role in the collective resilience of the individual and community within a politically violent context (Sousa, Haj-Yahia, Feldman \& Lee, 2013).

Scheper-Hughes (2008) completed studies and worked in the areas of political unrest says that the Western understanding of resilience is insufficient in other cultural contexts, especially in politically conflicted places where there is an everyday form of resilience within oppressed communities. Marie, Hannigan \& Johns (2018) assert that there is a near absence of research studies which investigate resilience within conflict areas and in underdeveloped or developing countries, and a lack of research studies that investigate resilience within an Arabic or Muslim cultural context. They clarify that few relevant studies on the resilience of Palestinians were found, particularly related to the fourth wave of resilience. Therefore, they recommend further studies in Gaza that include focus on resilience in children which draws on wider cultural contexts and responses.

This paper seeks to fill a knowledge gap within resiliency research and neglect of incorporating the cultural context of a strength-based proactive approach (SBPA) for building resilience in school children under political crisis taking into account the factor of gender.

The case of Gaza as a region under occupation and prolonged blockade of borders since 2006 and internal Palestinian division is a home to more than 931,200 children under the age of 18 , more than one-half children are school students, drop-out rate was $1.2 \%$ among school children, $1.2 \%$ of school children are engaged in paid and unpaid labour, and $0.9 \%$ of the children have at least one form of disability (PCBS, 2018). Palestinian children in the Gaza Strip experienced the variety of traumatic events, including bombardment, demolition of homes, witnessing killing and arrest of relatives, and arrest of relatives that caused post-traumatic disorder, depression and anxiety. These severely deteriorated children's sleep and cause uncontrollable fears among babies and children, causing anxiety, panic attacks and poor concentration (Thabit \& Thabit, 2015). Military trauma in middle childhood and stressful life-events in early adolescence formed a risk for post-traumatic stress disorder and depressive and decreased satisfaction with the quality of life in adolescence (Qouta, Punamäki, Montgomery \& El Sarraj, 2007). Likewise, Thabit (2017) states that the children living in Gaza have been exposed to and are suffering from a range of trauma and abuse, which out them at high risk factor for the development of mental health problems in young life and their continuation into adulthood and the next generation of parents.

\section{Rationale of the study}

Evidence exists that there is a relationship between inadequate existing resiliency in Gazan school children and the current poor education approaches (adult-cantered model) used by counsellors and teachers which are mainly focused on learning and lack protective measures and lack of partner- ship with family and community to promote wellbeing and resilience of school children. School children have manifested lack of social competence, problem-solving skills, autonomy and optimism. Therefore, enhancing resilience in school children requires new adapted practical, proactive, wellbeing and resilience-based approaches to be applied in a far more sustainable way than is currently practiced. This needs to be based on a thorough understanding of the current status of children resiliency and attributes of resilient child in Gaza based on strength-based approaches.

Despite the frequent calls of the various stakeholders to use the strength-based approach in building resilience in school children, but schools' counsellors misunderstand and undervalue the strength-based approach. Besides, none of the scholars have tackled the strength-based approach in building resiliency in school children in Gaza. Therefore, this research comes as an attempt to assist school counsellors, teachers, psychological professionals, and parents and other caregivers to understand the strength-based proactive approach that emphasises the strengths, capabilities and resources of children, families, school, and community.

The aim of this article was to assist schools' principals, counsellors and teachers within Gaza schools to apply effective and proactive approaches and social and emotional learning programs that enhance student's resilience, engagement and wellbeing.

\section{Methodology}

This research incorporates descriptive and correlational research designs and follows a multi-method approach to answer the main research question 'What are the interventions used by school counsellors in helping school-children in Gaza to be more resilient and aiding them in personal and school adjustment' via responding to following most pressing questions (Qs):

Q1: What is resilience? What are the factors that influence resilience?

Q2: To what extent has the concept of resilience been operationalised in real life practice and experience of existing well-established approaches?

Q3: How can a new conceptual resilience model be adapted based on the theoretical and practical aspects of the resilience?

Q4: How can the new conceptual resilience model be localised and applied to schools in Gaza city and other cities experiencing similar political instability?

All the above research questions are critical to be answered, since the resilience appears to be adopted as the ideal psychological approach across the globe. Q1 is answered through review of related articles on the concept and determinants of resilience. Q2 is explained via analysing existing well-established resilience models such as strengths-based model and a whole-school model. Q3 is tackled by forming Conceptual Strength- Based Proactive Approach (CSBPA) 
based on literature review and analysing strength-based and a whole-school models. Finally, Q4 is addressed via applying (CSBPA) to analyse the existing preparatory school educational models in Gaza to investigate their strengths, weaknesses, replicability and scalability in the Palestinian and regional school education.

\section{Sample size and sample distribution}

The research mapped the stakeholders as the source of information for qualitative and quantitative data. Those stakeholders included, counsellors, teachers, principals, families, staff of the Ministry of Education, and staff of educational NGOs related to preparatory governmental schools in Gaza City.

To ensure generalisation of research results, the researcher used a random sample size of 619 from the total population of 8805 children at preparatory (seventh, eighth and ninth grades) governmental schools in Gaza City. Such sample was used as a source of the quantitative data through survey questionnaires. Sample size calculator at a confidence level of $99 \%$ and confidence interval of $5 \%$ was used to ensure accuracy. The Lots Quality Assurance Sampling survey technique was used for sample distribution (USAID, 2011) to ensure that the research sample has the same characteristics of the total population. It is worth mentioning that 619 students responded to the survey questionnaires, reflecting an actual response rate of $100 \%$. The participants included 313 boys $(50.6 \%)$ and 306 girls (49.4\%). The age range was $12-15$ years, with a mean age of 13.5 years. Nearly, $34.9 \%$ of the children were in the seventh grade, $32.8 \%$ in the eighth grade and $32.3 \%$ in the ninth grade. Around 236 of children (38.1\%) were from east Gaza and 383 children (61.9\%) were from west Gaza. The majority of children $98.1 \%$ were from the urban areas. Nearly, $92.4 \%$ of the children live in owned homes, while $5.3 \%$ of them reside in rented houses. Regarding father's work, $21.8 \%$ of children's fathers have no work, $11.5 \%$ are employers, $15 \%$ are self-employed and $49.1 \%$ of children's fathers are employees or workers. In terms of father's education, $2.1 \%$ of children's fathers are uneducated, $5.7 \%$ had elementary school education, $11 \%$ had preparatory school education, $30.4 \%$ had secondary education and $50.8 \%$ of fathers had university and post graduate education. In relation to mother's education level, $1.5 \%$ of the mothers of children are uneducated, $3.4 \%$ had elementary education, $11 \%$ ) had preparatory education and $43.5 \%$ had secondary education. About $32.1 \%$ of the mothers completed their university education and about $8.6 \%$ completed their postgraduate studies. As to family income, about half $(52.5 \%)$ of the children have family monthly income lower than (NIS 2,000, equivalent to 550 USD), about one fifth (21.5) of them have family monthly income (2,001-3,000 NIS, equivalent to 550830 USD) and about $26 \%$ of the children have family monthly income (NIS 3,001-6,001 and above, equivalent to $830-1,660$ USD or more).
The researcher also considered an adequate sample size for the qualitative research that is enough for achieving saturation regarding perspectives of all the stakeholders. Saturation occurs when adding more participants to the research does not yield additional perspectives or information. Glaser and Strauss (1967) recommend the concept of saturation for achieving an appropriate sample size in qualitative researches. Creswell (1998) recommends five to (25) interviews and Morse (1994) suggests at least six interviews. However, the research included (12) interviews with purposefully selected principals and psychological experts and (12) focus groups with parents, teachers and counsellors, taking into consideration the saturation concept. Participants in focus groups and interviews consisted of 90 teachers and counsellors, including 12 males $(13 \%)$ and 78 females (87\%). The participants were six school principals, six psychologists and experts, and 29 children's parents. The parents who participated in focus groups have an age range of $30-50$ years.

\section{Variables of the study}

Resilience in school children (extent of having the capacity for successful adaptation despite challenging or threatening circumstances) was the dependent variable while internal and external strengths were the independent variables. Internal strengths variables were empowerment and self-control, self-concept, and social sensitivity, empathy \& cultural sensitivity. External strength variables were community cohesiveness, family, peers, school culture, learning at school, and INGOs \& Palestinian formal institutions and child protection and rights NGOs. The study included also gender (male and female) as a demographic variable.

\section{Data collection}

The research followed a mix-methodological, dynamic learning-oriented research approach to collect and analyse data. It was a flexible approach that combined quantitative (post positivism approach) and qualitative (constructivism approach/interpretive approach) methods. Information from qualitative methods were triangulated, cross-checked and validated with the view to conclude accurate and evidencebased research information and results with stakeholders. The qualitative method included data collection using literature review of relevant recent articles, thesis, studies, and reports that covered the knowledge gap, concepts in the research questions and research framework (hypothesis). It included also key informant interviews and focus groups with stakeholders represented by school counsellors, teachers/ educators, principals, parents, and experts in the field. At the beginning of each interview, participants were informed of their rights and were assured that their identities will not be revealed in any publications/reports and their information will remain confidential.

The quantitative method included data collection using self-administered survey questionnaire with school children. 
The researcher applied two-stage random sampling. At first, a list of all the preparatory governmental schools in the two regions (East Gaza, West Gaza) was created. Second, a list was prepared that involved all of the children in those two schools. Then, a list was stratified depending on the age and gender of the children. The final sample involved 20 classes of seventh, eighth, and ninth grade students. A survey questionnaire was translated from English to Arabic and then back-translated to English.

\section{Data analysis}

The research comprised qualitative data entry and analysis from document review, key informant interviews, focus groups using content analysis and findings of analysis are triangulated, cross-checked and validated. It included also quantitative data entry and analysis from survey questionnaires using statistical analysis such as descriptive statistics, testing validity, correlation and regression.

\section{Results}

In Figure 1, there were important themes with the core theme "resilience in school children" and other internal and external strengths. In our model the majority of children have the capacity for successful adaptation despite challenging circumstances. Fawzi, a father said, 'My daughter in $\mathrm{Al}$ Ramla Girls' Basic School has high ability to adapt and succeed and she can face difficulties and solve problems under the current changing circumstances in Gaza. However, she sometimes needs our help'. Likewise, Jaber, a father said, 'My son in Hetteen Boys' Basic School can adapt and succeed but we encourage him'. This indicates that the students in both sexes (males and females) in the Gaza City have the same ability to adapt and succeed despite the difficult surrounding circumstances.

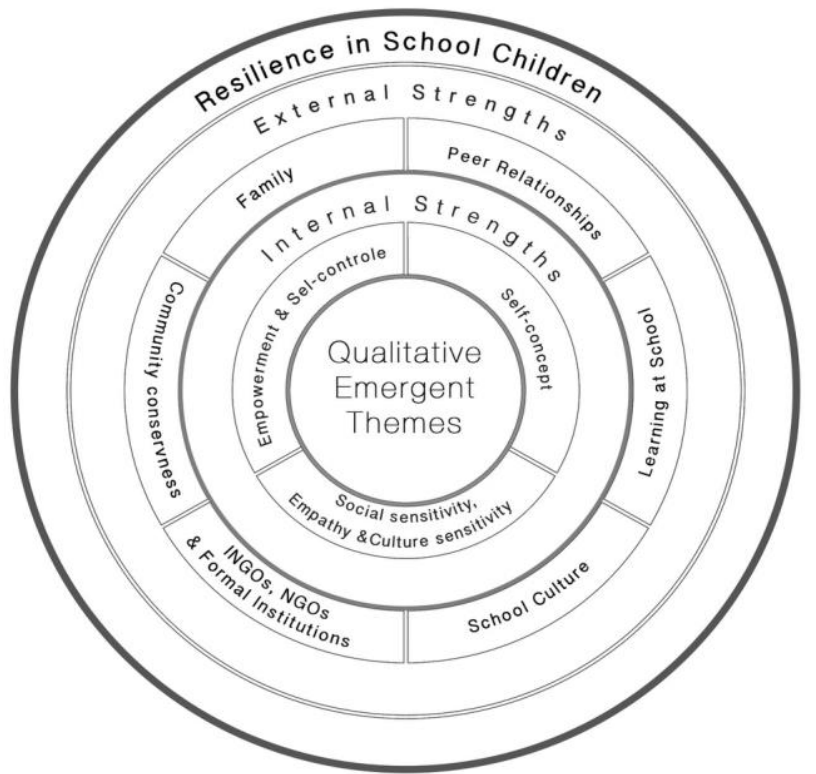

Figure 1. Emergent Themes from Qualitative Data.

\section{Findings from the qualitative method}

Resilience in children was the child's ability as an internal strength to control himself in difficult situations which lead to better overall health, socialization, intelligence, affectionate, positive thinking, and ability to solve problems. Alaa' an expert said, 'Factors that affect children's ability to control themselves in difficult situations include self-confidence, positive thinking and ability to solve problems, as well as the support others when needed'.

Self-concept is another internal strength factor which is affected by child's identity, his/her achievements, encouraging and motivating adults, his superiority over his peers, and body image. Marwan is a teacher at Anas Ben Malik Boys Basic School said, 'We encourage students to set life and educational objectives and advise them on achieving them'.

Social sensitivity, empathy and cultural sensitivity are building and shaping the cultural sensitivity in the child which include relationship with mother as the cornerstone of our culture, father, and extended family, in addition to television and the internet recently. Children are affected by socialisation and protection factors provided by the social environment, and other factors that negatively affect the formation of cultural sensitivity like the child's exposure to cruelty, violence, discrimination, inequality, injustice from society and negative comparisons. Hiam an expert said, 'Factors that contribute to building and shaping the cultural sensitivity in children include relationship with family, as well as the schools, places of worship and awareness in psychological support programs in schools and various institutions'.

Resilience in children included also external strengths such as community cohesiveness in which families keep up good relationship with neighbours and relatives to make the child feels supported, and that everyone cares for him and give him feeling of love, confidence, and acceptance.

Family is another external strength which builds a strong relationship with school. Suhaib is a father said, 'I regularly communicate with the school management and visit the school to follow up the academic performance of my daughter and solve any problem she faces. I also participate in all of the school's events'.

A good peer relationship is a very strong external strength for children offering opportunity to compete and build new interactions. Moreover, teachers and the principals as a part of the school culture create a supportive environment where the child being more discipline and controlled than being in the family or with peer groups. Majda is a counsellor at Mahfoz Nihnah Girls Basic School said, 'The school staff cooperate to create a comfortable and supportive school environment and to provide female students with all needed support'.

Inadequate topics related to resilience in the school curriculum are a weakness in children ability to build resilience. Amal is a principal at Nasrah Girls Basic School said, 'I think that the school curriculum of some grades of basic education contains few topics on resiliency, but these topics are inadequate for basic education stage'.

International organisations and Palestinian governmental and nongovernmental organisations manage programmes 
that deliver services to support building resiliency in children. Jamil, an expert said, 'There are many international institutions that deliver psychosocial programmes for children. These programs, if implemented effectively, are useful in enhancing children's strengths'. Ahmed, an expert said, 'The trend toward building resiliency has recently grown on the agenda of the local child protection and rights NGOs. However, most of the programmes have relief and recovery interventions, which are implemented immediately after wars on Gaza. On the other hand, few programmes aim directly to strengthen school children's resilience via addressing their behavioural problems, including violence and substance abuse'.

\section{Findings from the quantitative method}

\section{Awareness about building resiliency in school children}

Table 1 shows only $8.1 \%$ of students' respondents usually read about building resilience in school children which reflects the inadequate understanding of children resiliency in terms of their capability to cope successfully in the face of stress-related situations. The internet is found as the most reading source about building resiliency in school children.

Table 1. Awareness about building resiliency in school children.

\begin{tabular}{lcc}
\hline Item & Frequency & Percent \\
\hline Reading about building resiliency in school children & \\
\hline Usually & 50 & 8.1 \\
Sometimes & 286 & 46.2 \\
No & 283 & 45.7 \\
Total & 619 & 100.0 \\
\hline Children's reading sources & \\
\hline Magazines & 35 & 10.4 \\
Newspapers & 25 & 7.5 \\
Internet & 161 & 47.9 \\
Social media websites & 115 & 34.2 \\
Total & 336 & 100.0 \\
\hline Children's participation in workshops organised by civil society or- \\
ganisations & \\
\hline Yes & 195 & 31.5 \\
$\quad$ No & 424 & 68.5 \\
Total & 619 & 100.0 \\
\hline
\end{tabular}

Concept of resiliency

Table 2 explains that about two thirds of students assert that the concept of resiliency is integrated into school curriculum. It displays also that about a quarter of students' respondents are highly influenced by the concept of resiliency.
Table 2. Concept of resiliency.

\begin{tabular}{lcc}
\hline Item & Frequency & Percent \\
\hline Integration of concept of resiliency into school curriculum & \\
\hline Yes & 426 & 68.8 \\
No & 193 & 31.2 \\
Total & 619 & 100.0 \\
\hline Children's influence by concept of resiliency & & \\
\hline High influence & 117 & 27.5 \\
Normal influence & 234 & 54.9 \\
I do not know & 14 & 3.3 \\
Limited influence & 51 & 12.0 \\
No influence at all & 10 & 2.3 \\
Total & 426 & 100.0 \\
\hline
\end{tabular}

\section{Building resiliency in school children}

According to Table 3, three quarters of students agree that the school counsellor and teacher talk about building resiliency and ways to strengthen it. Table 3 indicates also that more than one third of students are highly influenced by what was stated by school counsellor and teacher.

Table 3. Building resiliency in school children.

\begin{tabular}{lcl}
\hline Item & Frequency & Percent \\
\hline \multicolumn{3}{c}{ Talking about building resiliency and ways to strengthen it } \\
\hline Yes & 465 & 75.1 \\
No & 154 & 24.9 \\
Total & 619 & 100.0 \\
\hline Degree of children's influence by what was stated by school coun- \\
sellor and teacher \\
\hline High influence & 171 & 36.8 \\
Normal influence & 213 & 45.8 \\
I do not know & 9 & 1.9 \\
Limited influence & 68 & 14.6 \\
No influence at all & 4 & .9 \\
Total & 465 & 100.0 \\
\hline
\end{tabular}

\section{Analysis of internal and external strength factors that contribute to building resilience}

Table 4 highlights high score (86\%) given by the students for having the capacity for successful adaptation despite challenging or threatening circumstances.

\section{Analysis of internal strength factors}

Table 5 shows that Students' respondents gave the highest score $(89.2 \%)$ for cultural and social sensitivity \& empathy followed by self-concept (87\%) and then gave the lowest score $(80 \%)$ for empowerment and self-control.

Table 4. Relative weights (scores) of students' capacity for successful adaptation.

\begin{tabular}{|c|c|c|c|c|c|c|c|c|}
\hline \multirow[t]{2}{*}{ No } & \multirow[b]{2}{*}{ Item } & \multicolumn{5}{|c|}{ Percentages of students' respondents } & \multirow{2}{*}{$\begin{array}{c}\text { Mean value } \\
\text { out of } 5\end{array}$} & \multirow{2}{*}{$\begin{array}{l}\text { Relative } \\
\text { weight } \\
\text { (score) }\end{array}$} \\
\hline & & $\begin{array}{c}\text { Strongly disagree } \\
1\end{array}$ & $\begin{array}{c}\text { Disagree } \\
2\end{array}$ & $\begin{array}{c}\text { Neutral } \\
3\end{array}$ & $\underset{4}{\text { Agree }}$ & $\begin{array}{c}\text { Strongly agree } \\
5\end{array}$ & & \\
\hline 1 & $\begin{array}{l}\text { Extent of having the capacity for suc- } \\
\text { cessful adaptation despite challenging } \\
\text { or threatening circumstances }\end{array}$ & 2.9 & 4.0 & 6.0 & 34.9 & 52.2 & 4.3 & $86.0 \%$ \\
\hline
\end{tabular}


Table 5. Relative weights (scores) of internal strength factors.

\begin{tabular}{|c|c|c|c|c|c|c|c|c|}
\hline \multirow[t]{2}{*}{$\overline{\mathrm{No}}$} & \multirow[b]{2}{*}{ Internal strength factors } & \multicolumn{5}{|c|}{ Percentages of students' respondents } & \multirow{2}{*}{\multicolumn{2}{|c|}{$\begin{array}{l}\text { Mean value Relative weight } \\
\text { out of } 5 \quad \text { (score) }\end{array}$}} \\
\hline & & $\begin{array}{c}\text { Strongly disagree } \\
1\end{array}$ & $\begin{array}{c}\text { Disagree } \\
2\end{array}$ & $\begin{array}{c}\text { Neutral } \\
3\end{array}$ & $\underset{4}{\text { Agree }}$ & $\begin{array}{c}\text { Strongly agree } \\
5\end{array}$ & & \\
\hline & Empowerment and self-control & 4.48 & 9.3 & 9.5 & 33.32 & 43.36 & 4.02 & $80.0 \%$ \\
\hline 2 & Self-concept & 2.28 & 3.84 & 6.89 & 32.19 & 54.76 & 4.3 & $87.0 \%$ \\
\hline 3 & Cultural and social sensitivity \& empathy & 1.08 & 2.56 & 6.02 & 29.76 & 60.58 & 4.46 & $89.2 \%$ \\
\hline
\end{tabular}

\section{Analysis of external strength factors}

According to Table 6, students' respondents gave the highest score $(90 \%)$ for child learning at school, followed by peers $(88 \%)$, family $(83 \%)$, school culture $(79.3 \%)$, commu- nity cohesiveness (76\%), and then gave the lowest score $(71.6 \%)$ for child protection and rights NGOs, Palestinian formal institutions at local and national levels, international NGOs (e.g., UNICEF).

Table 6. Relative weights (scores) of external strength factors.

\begin{tabular}{|c|c|c|c|c|c|c|c|}
\hline \multirow[b]{2}{*}{ External strength factors } & \multicolumn{5}{|c|}{ Percentages of students' respondents } & \multirow{2}{*}{$\begin{array}{l}\text { Mean value } \\
\text { out of } 5\end{array}$} & \multirow{2}{*}{$\begin{array}{l}\text { Relative weight } \\
\quad \text { (score) }\end{array}$} \\
\hline & $\begin{array}{c}\text { Strongly } \\
\text { disagree } \\
1 \\
\end{array}$ & $\begin{array}{c}\text { Disagree } \\
2\end{array}$ & $\begin{array}{c}\text { Neutral } \\
3\end{array}$ & $\begin{array}{c}\text { Agree } \\
4\end{array}$ & $\begin{array}{c}\text { Strongly } \\
\text { agree } \\
5 \\
\end{array}$ & & \\
\hline 4 Community cohesiveness & 8.63 & 10.45 & 13.1 & 33.40 & 34.45 & 3.8 & $76.0 \%$ \\
\hline 5 Family & 4.23 & 8.38 & 7.41 & 28.25 & 51.72 & 4.15 & $83.0 \%$ \\
\hline 6 Peers & 2.15 & 3.2 & 5.45 & 31.7 & 57.4 & 4.4 & $88.0 \%$ \\
\hline 7 School culture & 6.37 & 5.83 & 11.43 & 37.17 & 39.27 & 4.0 & $79.3 \%$ \\
\hline 8 Learning at school & 1.2 & 2.8 & 4.47 & 25.13 & 66.4 & 4.5 & $90.0 \%$ \\
\hline $\begin{array}{l}9 \text { Child protection and rights NGOs, Palestinian formal insti- } \\
\text { tutions at local and national levels, International NGOs }\end{array}$ & 10.44 & 14.52 & 21.07 & 29.7 & 24.22 & 3.58 & $71.6 \%$ \\
\hline
\end{tabular}

\section{Results of the research question}

Is there a statistically significant differences in the effect of internal strength factors (empowerment, self-control, selfconcept, cultural sensitivity, and social sensitivity) and external strength factors (community cohesion, family, peer group, school, school culture, learning at school, child protection and rights NGOs, Palestinian formal institutions at local and national levels, and International NGOs (e.g., UNICEF) on the extent to which children have the ability to adapt and succeed according to (gender variable)?

Table 7. Results of the ' $l$ test for the independent samples to detect the differences between the average of the internal and external strength factors and the extent of students' ability to adapt and succeed due to the gender (male, female) variable.

\begin{tabular}{|c|c|c|c|c|c|c|c|c|c|c|}
\hline \multirow[t]{2}{*}{ Internal strength factors } & \multicolumn{4}{|c|}{ Male } & \multicolumn{4}{|c|}{ Female } & \multirow[t]{2}{*}{$T$} & \multirow[t]{2}{*}{ Sig. } \\
\hline & $N$ & $M$ & $S D$ & Relative weight & $N$ & $M$ & $S D$ & Relative weight & & \\
\hline Empowerment and Self-Control & & 4.02 & 0.66 & $80.4 \%$ & & 4.07 & 0.56 & $81.4 \%$ & 1.17 & $0.242 / /$ \\
\hline Self-Concept & & 4.30 & 0.52 & $86.0 \%$ & & 4.37 & 0.41 & $87.4 \%$ & 1.66 & $0.098 / /$ \\
\hline $\begin{array}{l}\text { Cultural Sensitivity and Social Sensitivity } \\
\& \text { Empathy }\end{array}$ & & 4.51 & 0.61 & $90.2 \%$ & & 4.67 & 0.43 & $93.4 \%$ & 3.59 & $0.000 * *$ \\
\hline Total average & 313 & 4.27 & 0.43 & $85.4 \%$ & 306 & 4.30 & 0.33 & $86.0 \%$ & 1.13 & $0.259 / /$ \\
\hline \multirow[t]{2}{*}{ External strength factors } & \multicolumn{4}{|c|}{ Male } & \multicolumn{4}{|c|}{ Female } & $T$ & Sig. \\
\hline & $N$ & $M$ & $S D$ & Relative weight & $N$ & $M$ & $S D$ & Relative weight & & \\
\hline Community cohesiveness & & 3.81 & 0.85 & $76.2 \%$ & & 3,68 & 0.86 & $73.6 \%$ & 2.01 & $* 0.045$ \\
\hline Family & & 4.18 & 0.67 & $83.6 \%$ & & 4.11 & 0.61 & $82.2 \%$ & 1.44 & $/ / 0.150$ \\
\hline Peers & & 4.35 & 0.79 & $87.0 \%$ & & 4.43 & 0.83 & $88.6 \%$ & $1.18-$ & $/ / 0.239$ \\
\hline School culture & & 3.99 & 0.91 & $79.8 \%$ & & 3.95 & 0.88 & $79.0 \%$ & 0.623 & $/ / 0.534$ \\
\hline Learning at school & & 4.44 & 0.72 & $88.8 \%$ & & 4.61 & 0.51 & $92.2 \%$ & -3.36 & $0.001 * *$ \\
\hline $\begin{array}{l}\text { Child protection and rights NGOs - Pal- } \\
\text { estinian formal institutions at local and } \\
\text { national levels-International NGOs }\end{array}$ & & 3.60 & 0.72 & $72.0 \%$ & & 3.25 & 0.69 & $65.0 \%$ & 6.012 & $* * 0.000$ \\
\hline Total average & 313 & 4.06 & 0.53 & $80.1 \%$ & 306 & 4.0 & 0.483 & $80.0 \%$ & 1.443 & $/ / 0.150$ \\
\hline
\end{tabular}

Table 7 shows that there are no statistically significant differences (Significant at 0.01) between the averages of internal strengths factors to measure the extent of the ability to adapt and succeed in school children due to the gender vari- able (male and female) in the study sample in Gaza City, except for the cultural sensitivity and social sensitivity \& empathy factor (Significant at 0.05). Table 7 also illustrates that there are no statistically significant differences between the 
averages of external strengths factors in general to measure the extent of the ability to adapt and succeed in school children due to the gender variable (male and female children) in the study sample in Gaza City, except for learning at school in favour of females, the social cohesion, and the child protection and rights NGOs factors in favour of males.

\section{Discussion}

The results of both quantitative and qualitative phases of this study show that the majority of children have the ability to adapt and succeed despite the difficult circumstances surrounding them, but with great difficulties. The quantitative results demonstrate high score $(86 \%)$ given by students' respondents for having the capacity for successful adaptation despite challenging or threatening circumstances. These results correspond to Cénat, Derivois, Hébert, Amédée \& Karray (2018), in their research studying the multiple traumas and resilience experienced by the street children in Haiti. However, a large majority of street children present a moderate to very high level of resilience. These results are also consistent with Marie, Hannigan, \& Jones, (2018) who indicate that resilient Palestinian youth are capable to live normally, while they face risks and inadequate resources, due to social support they receive in their homes. Al Ajarma (2010) introduces highly resilient Palestinian children, who live in threatening political and security environment, and characterises drivers of children's resilience, such as arts, learning at school, caring family, friendly community and social support, and participation in political activities and awareness. It may be concluded that Palestinian school students have the capacity for successful adaptation and confronting learning and social problems under the prevailing stressful situation.

This study showed that only $8.1 \%$ of students' respondents who usually read about building resilience in school children indicating inadequate understanding of their resiliency in terms of their capability to cope successfully in the face of stress-related situations. The internet is found as the most used reading source, reflecting high access of children in Gaza to internet and social media platforms. Despite the usefulness of engaging children in resiliency workshops organised by civil society organisations as demonstrated by this study; more than two thirds of students' respondents have not participated in workshops on building their resiliency which clarifies the limited availability and accessibility of NGOs services that support children's resilience to cope with difficult events.

The results present that the value of including resilience topics in the school curriculum and continuous teaching of students about it. However, quantitative method shows that about two thirds of students' respondents assert that the concept of resiliency is integrated into school curriculum, and about quarter of students' respondents are highly influenced by the concept of resiliency, while more than half of student respondents are normally influenced and one-eighth are influenced limitedly. On the contrary, qualitative method shows that very few topics related to resiliency are integrated in the school curriculum, often indirectly. This reflects the need to focus on educating students on the role of resiliency factors in their development.

The quantitative method shows that three quarters of students' respondents agree that the school counsellor and teacher talk about building resiliency and ways to strengthen it, and more than one third of students' respondents are highly influenced by what was stated by school counsellor and teacher, while less than half of student respondents are normally influenced and one-seventh of student respondents are influenced limitedly. Oppositely, the qualitative method shows that teachers do not talk about resilience due to insufficient time and a large content of the curriculum. This highlights the need to train school counsellors and teachers on the role of resiliency factors in children development. These results correspond to Payton et al. (2008) who suggest that effective school programmes include a combination of knowledge, social and life skills, normative approaches, critical thinking and negotiation skills; and should be delivered as a part of a broader health and personal development curriculum that incorporates a focus on a range of social, physical and mental health issues. They also link to Woolf (2013) who asserts that the use of stories and game plays as the most effective instruction medium to advance social and emotional learning in school children, providing them a space to be more self-aware, motivated, and able to manage feelings and develop social skills.

The study results show that students' respondents gave $(80 \%)$ for the empowerment and self-control factors. It displays the necessity of having child positive thinking, ability to solve problems, positive body image, good health, achievements, and encouraging and motivating adults to have a positive self- concept and empowerment. In addition to the importance of providing care, love, respect, encouragement, trust comfort, and safe environment for children.

The study presents the significance of creating a supportive school environment where the child learns more discipline and control than in the family and peer group. This coincides with Waters (2011) who argues that students need to know that school staff care is unconditionally available for them and educators must value and start the change process with what is important to the student.

The study pinpoints the necessity of building a strong relationship between school and family. This conforms with Mathar (2013) who reflects that whole-school approach leads to a sustainable school that incorporates active and participatory teaching and learning not only through aspects of the curriculum but also through sustainable school operations as community and parents' involvement, long-term planning and monitoring and evaluation. Mathar calls also for an exchange between teachers, pupils, parents and experts from outside the school.

The study marks the advantage of joining a peer group for the child that which offers the opportunity to compete and for new interactions; merit of good relationship with 
neighbours and relatives to make the child feels supported, and that everyone cares for him and give him feeling of love, confidence, and acceptance.

The study declares that that there are no statistically significant differences (Significant at 0.01) between the averages of internal strengths factors to measure the extent of the ability to adapt and succeed in school children due to the gender variable (male and female) in the study sample in Gaza city, except for the cultural and social sensitivity \& empathy factor (Significant at 0.05). These results imply that females have a cultural and social sensitivity \& empathy and affection for others more than males which are attributed to biological nature of females who have a feeling of sympathy for others and love to provide support larger than males.

The results reveal that there are no statistically significant differences between the averages of external strengths factors in general to measure the extent of the ability to adapt and succeed in school children due to the gender variable (male and female) in the study sample in the Gaza City. The absence of differences between males and females is ascribed to the fact that both sexes are equally affected at this stage by the peer group and receive the same support from the family and culture. Except for learning at school in favour of females, this result is normal and the reason for this is that the females are more interested and attached to school than males. Accordingly, females are more affected than males by what they learned at school. The differences in the social cohesion and the child protection and rights NGOs factors are in favour of males due to the patriarchal system - male supremacy - gender power imbalances between men and women and hegemonic masculinity that predominates in the Palestinian society. Therefore, the impact of males is greater and male participation in activities organised by NGOs may be greater than the participation of females, as some conservative families in the Palestinian society may prevent girls from participating in activities implemented by NGOs.

\section{References}

Ager, A. (2013). Annual research review: resilience and child well-beingpublic policy implications. Journal of Child Psychology and Psychiatry, 54(4), 488-500.

Al Ajarma, Y. (2010). The role of the arts toward bealing trauma and building resilience in the Palestinian community ( $\mathrm{PhD}$ thesis, Lesley University, Cambridge, MA).

Al-Bataineh, A., Brenwall, L., Stalter, K., \& York, J. (2019). Student growth through goal setting. International Journal of Learning and Teaching, 11(4), 147-161. doi:10.18844/ijlt.v11i4.4329

Alberta. (2012). Creating Strength-Based and Schools Classrooms. Practice Guide for Classrooms and Schools. AMP Mentoring Resource Support: Toll free 1-888-342-6514, questions@albertamentors.ca.

Almedom, A. M. \& Glandon, D. (2007). Resilience is not the absence of PTSD any more than health is the absence of disease. Journal of Loss and Trauma, 12(2), 127-143.

\section{Conclusions}

This research work comes as the first effort to develop CSBPA model for the case of Gaza city and other similar cities experiencing political instability to be used by counsellors and psychologists to apply effective and proactive approaches and social and emotional learning programmes that enhance students' resilience, engagement and wellbeing. Therefore, the conceptual threads and correspondent priority indicators of CSBPA model should be emerged at the level of educational institutions.

The strength-based approach should be applied to foster and support the academic learning, resilience and wellbeing of children, enables children to develop personal and social capabilities and solve the problem of psychological disorders and low academic achievement of school children. This will- to a large extent-lead to solve behavioural and educational problems in children, enhance their ability to adapt and deal with crisis more strongly and better, and reduce the psychological effects of the difficult crisis.

\section{Study limitation}

There were few limitations for this study, such as difficulties in collecting data from students at governmental schools and their families specially in border areas eastern Gaza city and although the use of mixed- methodological approach to collect and analyse data was useful and gave more accurate results but required great effort from the researcher.

\section{Study delimitation}

The study would be more valuable if we from the beginning tried to study the post traumatic growth (PTG) as a positive consequence to stress and trauma. Another thing we could add something about coping strategies of children and mothers to find the relation with resilience and PTG.

Alvord, M. K. \& Grados, J. J. (2005). Enhancing resilience in children: A proactive approach. Professional Psychology: Research and Practice, 36(3), 238-245.

Anthony, E. J. (1987). Risk, vulnerability, and resilience: an overview. In The invulnerable child (pp. 3-48).

Barton, W. H. (2005). Methodological challenge in the study of resilience. In M. Ungar (Ed.), Handbook for working with children and youth: pathways to resilience across cultures and contexts (pp. 135-147). Thousand Oaks, CA: Sage.

Beardslee, W. R., Solantaus, T. S., Morgan, B. S., Gladstone, T. R. \& Kowalenko, N. M. (2012). Preventive interventions for children of parents with depression: international perspectives. Medical Journal of Australia, 196(7), 23.

Babayigit, A. \& Okray, Z. (2018). Review of the relationship between depression and life satisfaction among university students. Global Journal of Psychology Research: New Trends and Issues, 8(3), 117-128. doi:10.18844/gjpr.v8i3.457 
Benson P. L. (1997). All kids are our kids. Minneapolis, MN: Search Institute. Bosworth, K. \& Earthman, E. (2002). From theory to practice: school leaders' perspectives on resiliency. Journal of Clinical Psychology, 58(3), 299306.

Bozic, N. (2013). Developing a strength-based approach to educational psychology practice: a multiple case study. Educational and Child Psychology, $30(4), 18-29$.

Brasler, P. (2001). Developing strengths-based treatment plans. Alexandria, VA: United Methodist Family Services.

Brownlee, K., Rawana, E. P., \& MacArtthur, J. (2012). Implementation of a strengths-based approach to teaching in an elementary School. Journal of Teaching and Learning, 8(1).

Cénat, J. M., Derivois, D., Hébert, M., Amédée, L. M. \& Karray, A. (2018). Multiple traumas and resilience among street children in Haiti: psychopathology of survival. Child Abuse \& Neglect, 79, 85-97.

Chu, P., Sen, Saucier, D. A., \& Hafner, E. (2010). Meta-analysis of the relationships between social support and well-being in children and adolescents. Journal of Social and Clinical Psychology, 29(6), 624-645. 10.

Colville, T. (2013). Strengths-based approaches in multi-agency meetings: the development of theory and practice. The British Psychological Society, $30,100-123$

Creswell, J. W. (1998). Qualitative inquiry and research design: choosing among five traditions. Thousand Oaks, CA: Sage Publications.

Cetinkaya, L. (2019). The usage of social network services in school management and their effects. World Journal on Educational Technology: Current Issues, 11(1), 116-127. doi:10.18844/wjet.v11i1.4014

Dukmak, S. \& Ishtaiwa, F. F. (2015). Factors influencing the academic achievement of students in the preparatory and secondary schools of the United Arab Emirates. European Journal of Social Sciences, 46(2), 132148.

Dumont, M. \& Provost, M. A. (1999). Resilience in adolescents: protective role of social support, coping strategies, self-esteem, and social activities on experience of stress and depression. Journal of Youth and Adolescence, 28(3), 343-363.

Freitas, A. L. \& Downey, G. (1998). Resilience: a dynamic perspective. International Journal of Behavioral Development, 22(2), 263-285.

Garcia-Dia, M. J., DiNapoli, J. M., Garcia-Ona, L., Jakubowski, R. \& O'flaherty, D. (2013). Concept analysis: resilience. Archives of Psychiatric Nursing, 27(6), 264-270.

Garmezy, N. (1996). Reflections and commentary on risk, resilience, and development. In Stress, risk, and resilience in children and adolescents: processes, mechanisms, and interventions (pp. 1-18).

Garmezy, N., \& Masten, A. (1994). Chronic adversities. Child and Adolescent Psychiatry, 3, 191-208.

Glaser, B. G. \& Strauss, A. L. (1967). he discovery of grounded theory: strategies for qualitative research. Piscataway, NJ: Transaction.

Go, M., Chu, C. M., Barlas, J. \& Chng, G. S. (2017). The role of strengths in anger and conduct problems in maltreated adolescents. Child Abuse \& Neglect, 67, 22-31. doi:10.1016/j.chiabu.2017.01.028

Hollenbeck, J. \& Morris, M. (2016). Evaluating student participation: focus on strengths in your school-based evaluation.

Hughes, G. (2014). Finding a voice through 'The Tree of Life': a strengthbased approach to mental health for refugee children and families in schools. Clinical Child Psychology and Psychiatry, 19(1), 139-153.

Jenney, A., Allagia, R. \& Niepage, M. (2016). The lie is that it's not going to get better": narratives of resilience from childhood exposure to intimate partner violence.

Johnson, G. M. (1997). Resilient at-risk students in the inner-city. McGill Journal of Education/Revue des sciences de l'éducation de McGill, 32(1), 35-50.

Karatas, Z., Tagay, O. \& Cakar, F. S. (2016). School attachment and peer bullying as the predictors of early adolescents' resilience. Global Journal of Guidance and Counseling in Schools: Current Perspectives, 6(1), 02-10. doi:10.18844/gjgc.v6i1.579

Lou, Y., Taylor, E. P., \& Di Folco, S. (2018). Resilience and resilience factors in children in residential care: a systematic review. Children and Youth Services Review, 89, 83-92.

Lotfi, R. (2017). Literature review on assessment models of the quality of training devices. New Trends and Issues Proceedings on Humanities and Social Sciences, 4(1), 481-495. doi:10.18844/prosoc.v4i1.2291
Luthar, S. S., Cicchetti, D., \&Becker, B. (2000). The construct of resilience: a critical evaluation and guidelines for future work. Child Development, $71,543-562$.

Mahedy, L., Harold, G. T., Maughan, B., Gardner, F., Araya, R., Jones, R. B., ... \& Collishaw, S. (2018). Resilience in high-risk adolescents of mothers with recurrent depressive disorder: The contribution of fathers. Journal of Adolescence, 65, 207-218.

Marie, M., Hannigan, B., \& Jones, A. (2018). Social ecology of resilience and Sumud of Palestinians. Health, 22(1), 20-35.

Masten, A. S. \& Coatsworth, J. D. (1998). The development of competence in favourable and unfavorable environments: lessons from research on successful children. American Psychologist, 53, 205-220.

Masten, A. S. (2001). Ordinary magic: resilience processes in development. American Psychologist, 56(3), 227.

Masten, A. S. (2007). Resilience in developing systems: progress and promise as the fourth wave rises. Development and Psychopathology, 19(3), 921930

Masten, A. S., \& Garmezy, N. (1985). Risk, vulnerability, and protective factors in developmental psychopathology. In Advances in clinical child psychology (pp. 1-52). Boston, MA: Springer.

Masten, A. S., Best, K. M., \& Garmezy, N. (1990). Resilience and development: Contributions from the study of children who overcome adversity. Development and Psychopathology, 2(4), 425-444.

Masten, A. S., Hubbard, J. J., Gest, S. D., Tellegen, A., Garmezy, N., \& Ramirez, M. (1999). Competence in the context of adversity: pathways to resilience and maladaptation from childhood to late adolescence. Development and Psychopathology, 11(1), 143-169.

Mathar, R. (2013). Concept paper: the concept of whole school approach-a platform for school development with focus on sustainable development.

McCann, C. M., Beddoe, E., McCormick, K., Huggard, P., Kedge, S., Adamson, C., \& Huggard, J. (2013). Resilience in the health professions: a review of recent literature. International Journal of Wellbeing, 3(1).

McCashen, W. (2005). The strengths approach. Victoria: St. Luke's Innovative Resources.

McDonald, G., Jackson, D., Wilkes, L. \& Vickers, M. (2013). Personal resilience in nurses and midwives: effects of a work-based educational intervention. Contemporary Nurse, 45(1), 134-143.

McGillivray, C. J. \& Pidgeon, A. M. (2015). Resilience attributes among university students: a comparative study of psychological distress, sleep disturbances and mindfulness. European Scientific Journal, 11(5), 33.

Morse, J. M. (1994). Designing funded qualitative research. In Denizin, N. K. \& Lincoln, Y. S. (Eds.), Handbook of qualitative research (2nd ed). Thousand Oaks, CA: Sage.

Mukhopadhyay, L. (2010). Development of resilience among school children against violence. Procedia Social and Behavioural Sciences, 5, 455-458.

Namy, S., Carlson, C., Pala, A. N., Faris, D., Knight, L., Allen, E., ... Naker, D. (2017). Gender, violence and resilience among Ugandan adolescents. Child Abuse \& Neglect, 70, 303-314.

O'Connell, D. (2006). Brief literature review on strength-based teaching and counselling. Research and draft prepared for the Metropolitan Action Committee on Violence against Women and Children (METRA C).

Palestinian Central Bureau of Statistics (PCBS). (2018). Palestinian Children's Day 2018 (p. 1).

Payton, J. W., Weissberg, R. P. Durlak, J. A., Dymnicki, A. B., Taylor, R. D. \& Schellinger, K. B. (2008). The positive impact of social and emotional learning for Kindergarten to eighth grade students: findings from three scientific reviews. Chicago, IL: Collaborative for Academic, Social, and emotional Learning.

Plotnikova, N., \& Strukov, E. N. (2019). Integration of teamwork and critical thinking skills in the process of teaching students. Cypriot Journal of Educational Sciences, 14(1), 1-10. doi.org/10.18844/cjes.v14i1.4031

Pinar, S. E., Yildirim, G., \& Sayin, N. (2018). Investigating the psychological resilience, self-confidence and problem-solving skills of midwife candidates. Nurse Education Today, 64, 144-149.

Qouta, S., Punamäki, R. L., Montgomery, E., \& El Sarraj, E. (2007). Predictors of psychological distress and positive resources among Palestinian adolescents: trauma, child, and mothering characteristics. Child Abuse \& Neglect, 31(7), 699-717. 
Ratanavivan, W. (2015). Using Motivational Interviewing as a strength-based approach with children in a disciplinary alternative education programme (p. 2) (PhD Dissertation, Texas A\&M University-Corpus Christi Corpus Christi, Texas)

Rojas, L. F. (2015). Factors affecting academic resilience in middle school students: a case study. Gist Education and Learning Research Journal, (11), 63-78; ISSN1692-5777.

Rowe, F. \& Stewart, D.E. (2009). Promoting connectedness through whole-school approaches, a quantitative study. Health Education, 109(5), 396-413.

Rutter, M. (1979). Protective factors in children's responses to stress and disadvantage. Annals of the Academy of Medicine, Singapore, 8(3), 324-338.

Rutter, M. (1987). Psychosocial resilience and protective mechanisms. American Journal of Orthopsychiatry, 57(3), 316.

Rutter, M. (2006). Implications of resilience concepts for scientific. understanding. Annals of the New York Academy of Sciences, 1094(1), 1-12.

Rutter, M. (2012). Resilience as a dynamic concept. Development and psychopathology, 24(2), 335-344.

Sagone, E. \& Elvira De Caroli, M. (2016). Are value priorities related to dispositional optimism and resilience? A correlational study. Contemporary Educational Researches Journal, 6(1), 11-20. doi:10.18844/cerj.v6i1.481.

Scheper-Hughes, N. (2008). A talent for life: Reflections on human vulnerability and resilience. Ethnos, 73(1), 25-56.

Seligman, M. E., Ernst, R. M., Gillham, J., Reivich, K., \& Linkins, M. (2009). Positive education: positive psychology and classroom interventions. Oxford review of education, 35(3), 293-311.

Soria, K. M., \& Stubblefield, R. (2015). Knowing me, knowing you: building strengths awareness, belonging, and persistence in higher education. Journal of College Student Retention: Research, Theory \& Practice, 17(3), 351372.

Sousa, C. A., Haj-Yahia, M. M., Feldman, G., \& Lee, J. (2013). Individual and collective dimensions of resilience within political violence. Trauma, Violence, \& Abuse, 14(3), 235-254.
Southwick, S. M., Bonanno, G. A., Masten, A. S., Panter-Brick, C. \& Yehuda, R. (2014). Resilience definitions, theory, and challenges: interdisciplinary perspectives. European Journal of Psych Traumatology, 5(1), 25338.

Szeri, C., Sahin, S., Cevahir, R., \& Say, M. (2010). Problem solving skills of the nursing and midwifery students and influential factors. Revista Eletrônica de Enfermagem, 12(4).

Thabet, A. A. M. (2017). Palestinian children: victims of decades of violence and trauma. JOJ Nurse Health Care, 2(3).

Thabet, A. A., \& Thabet, S. (2015). Trauma, PTSD, anxiety, and resilience in Palestinian children in the Gaza strip. British Journal of Education, Society \& Behavioural Science, 11(1), 1-13.

Trujillo, S. (2017). Beyond barriers: re-thinking education abroad using a strengthsbased approach.

Ungar, M. (2008). Resilience across cultures. The British Journal of Social Work, 38(2), 218-235.

Ungar, M. (2012). Social ecologies and their contribution to resilience. In The social ecology of resilience (pp. 13-31). New York, NY: Springer.

Ungar, M., Brown, M., Liebenberg, L. \& Othman, R. (2007). Unique pathways to resilience across cultures. Adolescence, 42(166), 287.

United States Agency for International Development (USAID) (2011). 2011 lot quality assurance sampling survey in Liberia.

Walsh, M. E. \& Park-Taylor, J. (2005). Comprehensive schooling and interprofessional collaboration: theory, research, and practice. Yearbook of the National Society for the Study of Education, 102(2), 8-44.

Waters, L. (2011). A review of school-based positive psychology interventions. Australian Educational and Development Psychologist, 28(2), 75-90.

Wernere,. E. \&Smith, R. (1982) Vulnerable, but invincible: a longitudinal study of resilient children and youth. New York: McGraw-Hill.

Woolf, A.M. (2013). Social and emotional aspects of learning: teaching and learning or playing and becoming. Pastoral Care in Education: An International Journal Of Personal, Social And Emotional Development, 31(1), 28-42.

Zhao, F., Guo, Y., Suhonen, R. \& Leino-Kilpi, H. (2016). Subjective wellbeing and its association with peer caring and resilience among nursing vs medical students: a questionnaire study. Nurse Education Today, 37, $108-113$ 